\title{
Insecta, Ephemeroptera, Ephemerellidae, Attenella margarita (Needham, 1927): Southeastern range extension to North Carolina, USA
}

\author{
Luke M. Jacobus ${ }^{1 *}$ and Eric D. Fleek ${ }^{2}$ \\ 1 Indiana University, Department of Biology, 1001 East Third Street, Bloomington, IN, 47405, USA. \\ 2 Environmental Sciences Section, North Carolina Division of Water Quality, 4401 Reedy Creek Road, Raleigh, NC, 27606, USA \\ * Corresponding author. E-mail: lukemjacobus@alumni.purdue.edu
}

\begin{abstract}
New data from the Great Smoky Mountains, in Swain County, North Carolina, USA, extend the geographic range of Attenella margarita (Needham, 1927) (Insecta, Ephemeroptera, Ephemerellidae) southeast by approximately 1,300 $\mathrm{km}$. We confirm that $A$. margarita has a disjunct east-west distribution in North America, which is rare among mayflies. Head, thoracic and abdominal characters for distinguishing larvae of $A$. margarita from the sympatric species, $A$. attenuata (McDunnough, 1925), are illustrated and discussed.
\end{abstract}

Needham (1927) described Ephemerella margarita Needham, 1927, (Ephemeroptera: Ephemerellidae) based on larvae from Utah, USA (Traver 1935). Allen (1980) established the present binomial combination, Attenella margarita, by elevating subgenera of Ephemerella Walsh to genus status. Attenella margarita larvae (Figure 1) are distinguishable from other Attenella Edmunds species by having the following combination of characteristics: abdominal terga four through eight with short and blunt, paired spines; most abdominal sterna with brown transverse bands on their lateral margins (Figure 3); prothorax with paired spines small (Figure 5); and occiput without paired spines (Figure 5) (Allen and Edmunds 1961). We have seen the sternal coloration pattern variably expressed on some other Attenella species, such as the sympatric $A$. attenuata (McDunnough, 1925), (e.g.
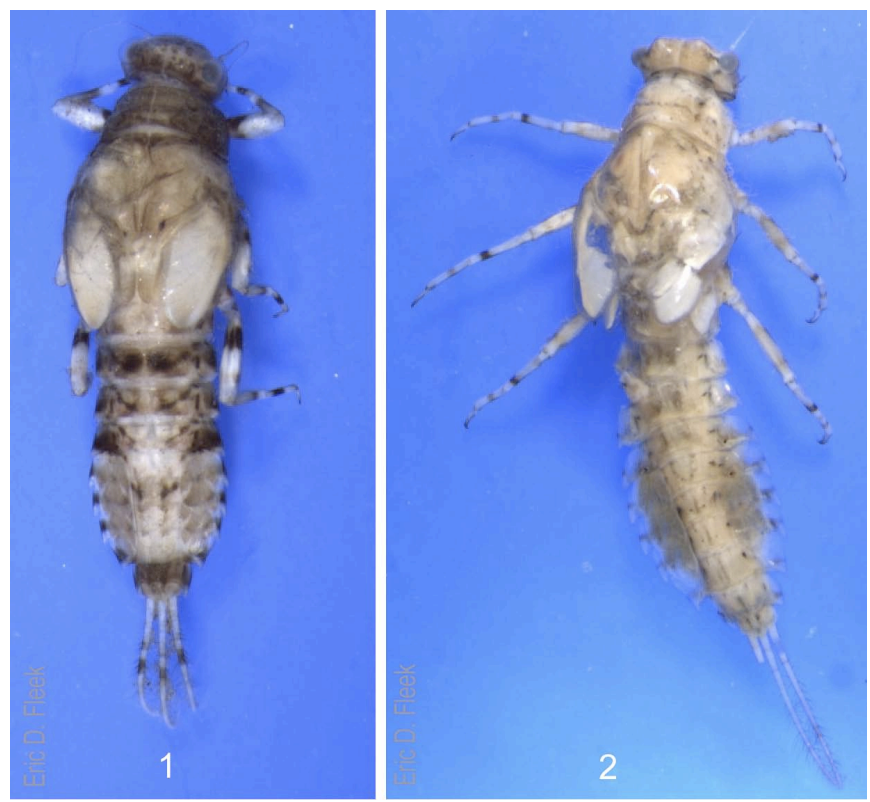

FIGURES 1 and 2. Attenella margarita (1) and Attenella attenuata (2), dorsal habitus.
Figure 4), so its diagnostic utility is limited. Adults were associated with Needham's (1927) larvae tentatively by McDunnough (1931) and Allen and Edmunds (1961).

Jacobus and McCafferty (2008) recently reviewed the systematics of Attenella. The genus is restricted to North America and solely comprises the tribe Attenellini McCafferty of the subfamily Timpanoginae Allen. McCafferty and Wang (1994) hypothesized cladistic relationships within the genus, and McCafferty (1977; 2000), McCafferty and Wang (2000), McCafferty et al. (2003), Kluge (2004) and Jacobus and McCafferty (2006) have discussed its relationships to other ephemerellid genera, primarily those considered part of the subfamily Timpanoginae. Ogden etal. (2009) provided molecular data for A. margarita and discussed alternative phylogenetic placements of the genus within Ephemerellidae based on these data, introducing the possibility that Attenella might be an aberrant member of the group that currently is considered as the subfamily Ephemerellinae.
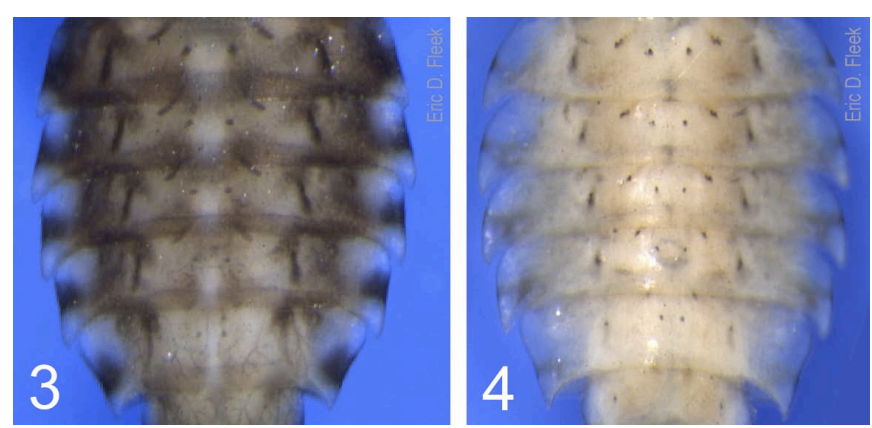

Figures 3 and 4. Attenella margarita (3) and Attenella attenuata (4), abdominal sterna.

Attenella margarita is relatively widespread in western North America, and it has a range that extends from British Columbia and Alberta, in Canada, south to California and New Mexico, in the USA (Allen and Edmunds 1961; McCafferty et al. 1997; McCafferty and Randolph 1998; Meyer and McCafferty 2008). McDunnough (1931) was 
the first to report individuals attributable to A. margarita from an apparently disjunct eastern North American population. Since then, A. margarita has been recorded from an eastern range that extends from Nova Scotia and New Brunswick, in Canada, south to the USA states of Minnesota in the west and Connecticut in the east (Allen and Edmunds 1961; Lager et al. 1982; Burian and Bednarik 1994; McCafferty and Randolph 1998).

McCafferty and Meyer (2007a) listed A. attenuata, rather than $A$. margarita, as an example of a North American mayfly species with disjunct eastern and western populations. This must represent an inadvertent error, because $A$. attenuata is not known to occur any further west than Missouri and Arkansas, and the species has a somewhat continuous distribution within its range (Allen and Edmunds 1961; Berner 1977; McCafferty and Provonsha 1978; Sarver and Kondratieff 1997; Randolph and McCafferty 1998; Ferro and Sites 2007). An old misidentification of $A$. attenuata from British Columbia (Walley 1927) probably is the source of confusion. McCafferty and Randolph (1998: 58) indicated that these data (Walley 1927) were based on misidentified $A$. margarita, and they provided additional corroborating data for the latter species from British Columbia.
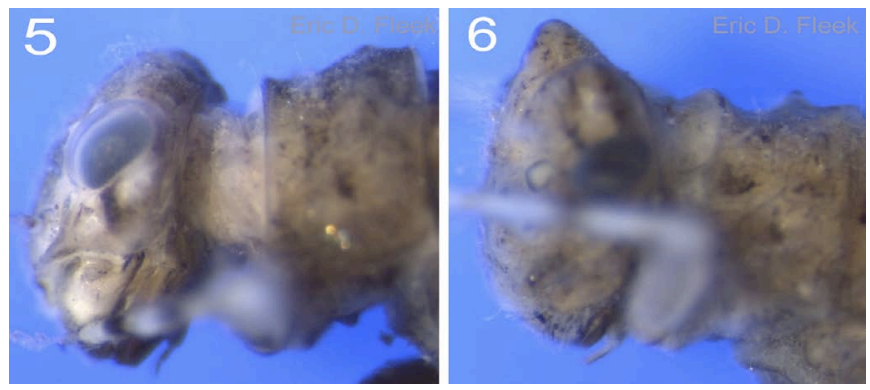

FIgURES 5 and 6. Attenella margarita (5) and Attenella attenuata (6), dorsal habitus.

Allen and Edmunds (1961) noted inconsistent coloration differences between the eastern and western populations of $A$. margarita, but these populations are otherwise morphologically inseparable. Allen and Edmunds (1961), Hawkins (1985) and Chandler et al. (2006) have discussed aspects of the biology of $A$. margarita.

We provide data that extend the recorded eastern range of $A$. margarita south by approximately $1300 \mathrm{~km}$ and that establish a North Carolina record for the species. These data are as follows: USA, North Carolina, Swain County, Great Smoky Mountains National Park, Eagle Creek, near mouth, $35^{\circ} 29^{\prime} 8^{\prime \prime} \mathrm{N}, 8^{\circ} 46^{\prime} 27^{\prime \prime} \mathrm{W}$; elevation 528.2 m; 3-VIII-2005; Eric D. Fleek, Trish MacPherson, Cathy Tyndall, collectors; sample number 9679. This location is in the Little Tennessee drainage basin and the southern metasedimentary mountains ecoregion (Griffith et al. 2002). These record data (McCafferty 2001) substantiate Parker et al. (2007) inclusion of A. margarita in a list of species from Great Smoky Mountains National Park, USA.

Our material of $A$. margarita (Figures 1, 3, 5) was collected together with some of our $A$. attenuata comparative material (Figures 2, 4, 6) and demonstrates discreet morphological differences from the latter species, as discussed above. Additional comparative material of $A$. attenuata was examined from the Level IV Sandhills ecoregion (Griffith et al. 2002) of North Carolina: Richmond County, Lumber River Basin, Naked Creek, $35^{\circ} 4^{\prime} 55^{\prime \prime} \mathrm{N}, 7^{\circ} 35^{\prime} 25^{\prime \prime} \mathrm{W}, 10-\mathrm{VII}-2006$, sample number 9966. All material examined is deposited with the North Carolina Division of Water Quality, Raleigh, North Carolina, USA.

Randolph and McCafferty (1998) cited McCafferty et al. (1993) when discussing the distribution pattern of A. margarita, noting "a north boreal band continuing to the extreme Northeast" from the West. McCafferty et al. (1993) did not document such a boreal band, and we have found no data that indicate such a continuous distribution, although it is possible. To date, $A$. margarita has not been reported from areas of central and far northern Canada and USA, and we have seen no specimens from these areas. Furthermore, McCafferty and Meyer (2007b) did not include $A$. margarita in their list of species with more or less continuous transcontinental distribution patterns. Thus, based on present record data and our observations, we conclude that $A$. margarita is a bonafide example of a mayfly species with a disjunct east-west distribution in North America, being essentially absent from the Far North and the central Great Plains.

Such disjunct east-west distributions are rare among species of North American mayflies, with only two others being documented: Anthopotamus verticis (Say, 1839) (Potamanthidae) and Cinygmula subaequalis (Banks, 1914) (Heptageniidae) (McCafferty and Meyer 2007a). Based on current taxonomy, Ephemerella dorothea Needham, 1908, (Ephemerellidae) could prove to be another species with a similar, disjunct east-west distribution (Jacobus and McCafferty 2003), but further study of Ephemerella species systematics is needed (Alexander et al. 2009) before this can be concluded with certainty.

Acknowledgments: We thank Trish Finn MacPherson (Apex, North Carolina, USA) for drawing our attention to $A$. margarita in North Carolina through her initial identification of specimens. Comments from an anonymous reviewer helped us to improve this paper.

\section{Literature Cited}

Alexander, L.C., M. Delion, D.J. Hawthorne, W.O. Lamp and D.H. Funk. 2009. Mitochondrial lineages and DNA barcoding of closely related species in the mayfly genus Ephemerella (Ephemeroptera:Ephemerellidae). Journal of the North American Benthological Society 28(3): 584-595.

Allen, R.K. 1980. Geographic distribution and reclassification of the subfamily Ephemerellinae (Ephemeroptera: Ephemerellidae); p. 71-91 In: J.F. Flannagan and K. E. Marshall (eds.). Advances in Ephemeroptera Biology. New York: Plenum.

Allen, R.K. and G.F.Jr. Edmunds. 1961. A revision of the genus Ephemerella (Ephemeroptera: Ephemerellidae) III. The subgenus Attenuatella. Journal of the Kansas Entomological Society 34(4): 161-173.

Berner, L. 1977. Distributional patterns of southeastern mayflies (Ephemeroptera). Bulletin of the Florida State Museum, Biological Sciences 22(1): 1-56.

Burian, S.K. and A.F. Bednarik. 1994. The mayflies (Ephemeroptera) of Connecticut: an initial faunal survey. Entomological News 105(4): 204-216.

Chandler, D.S., G.D. Whitmore, S.K. Burian and J.F. Burger. 2006. The mayflies (Ephemeroptera) of New Hampshire: Seasonality and diversity of the stream fauna. Transactions of the American Entomological Society 132(1+2): 25-73.

Ferro, M.L. and R.W. Sites. 2007. The Ephemeroptera, Plecoptera, and Trichoptera of Missouri State Parks, with notes on biomonitoring, mesohabitat associations, and distribution. Journal of the Kansas Entomological Society 80(2): 105-129.

Griffith, G.E., J.M. Omernik, J.A. Comstock, M.P. Schafale, W.H. McNab, D.R. Lenat, T.F. MacPherson, J.B. Glover and V.B. Shelburne. 2002. Ecoregions of North Carolina and South Carolina. (Color poster with 
map, descriptive text, summary tables and photographs). Reston: United States Geological Survey (map scale 1:1,500,000).

Hawkins, C.P. 1985. Food-habits of species of ephemerellid mayflies (Ephemeroptera, Insecta) in streams of Oregon. American Midland Naturalist 113(2): 343-352.

Jacobus, L.M. and W.P. McCafferty. 2003. Revisionary contributions to North American Ephemerella and Serratella (Ephemeroptera: Ephemerellidae). Journal of the New York Entomological Society 111(4): 174-193.

Jacobus, L.M. and W.P. McCafferty. 2006. Reevaluation of the phylogeny of the Ephemeroptera Infraorder Pannota (Furcatergalia), with adjustments to higher classification. Transactions of the American Entomological Society 132(3+4): 81-90, 429-430.

Jacobus, L. M. and W. P. McCafferty. 2008. Revision of Ephemerellidae genera (Ephemeroptera). Transactions of the American Entomological Society 134(1+2): 185-274.

Kluge, N. 2004. The phylogenetic system of Ephemeroptera. Dordrecht: Kluwer. 456 pp.

Lager, T.M., M.D. Johnson and W.P. McCafferty. 1982. The mayflies of northeastern Minnesota (Ephemeroptera). Proceedings of the Entomological Society of Washington 84(4): 729-741.

McCafferty, W.P. 1977. Biosystematics of Dannella and related subgenera of Ephemerella (Ephemeroptera: Ephemerellidae). Annals of the Entomological Society of America 70(6): 881-889.

McCafferty, W.P. 2000. A hierarchical classification of the Timpanoginae (Ephemeroptera: Ephemerellidae) and description of a new species from Quebec. Annales de Limnologie 36(3): 157-161.

McCafferty, W.P. 2001. Reporting species record data. Entomological News 111(4): 311-312.

McCafferty, W.P. and M.D. Meyer. 2007a. An extreme range extension and disjunction for the Ephemeroptera family Potamanthidae in North America. Proceedings of the Entomological Society of Washington 109(3): 737-738.

McCafferty, W.P. and M.D. Meyer. 2007b. Insecta, Ephemeroptera: Transcontinental range extensions in western North America. Check List 3(1): 51-54.

McCafferty, W.P. and R.P. Randolph. 1998. Canada mayflies: A faunistic compendium. Proceedings of the Entomological Society of Ontario 129: 47-97.

McCafferty, W.P. and A.V. Provonsha. 1978. The Ephemeroptera of mountainous Arkansas. Journal of the Kansas Entomological Society 51(3): 360-379.

McCafferty, W.P. and T.Q. Wang. 1994. Phylogenetics and the classification of the Timpanoga complex (Ephemeroptera: Ephemerellidae). Journal of the North American Benthological Society 13(4): 569-579.

McCafferty, W.P. and T.Q. Wang. 2000. Phylogenetic systematics of the major lineages of pannote mayflies (Ephemeroptera: Pannota). Transactions of the American Entomological Society 126(1): 9-101.
McCafferty, W.P., R.S. Durfee and B.C. Kondratieff. 1993. Colorado mayflies (Ephemeroptera): an annotated inventory. Southwestern Naturalist 38(3): 252-274.

McCafferty, W.P., L.M. Jacobus and T.Q. Wang. 2003. Phylogenetics and the reconfirmation of Dentatella Allen (Ephemeroptera: Ephemerellidae). Proceedings of the Entomological Society of Washington 105(3): 786788.

McCafferty, W.P., C.R. Lugo-Ortiz and G.Z. Jacobi. 1997. Mayfly fauna of New Mexico. Great Basin Naturalist 57(4): 283-314.

Meyer, M.D. and W.P.McCafferty. 2008. Mayflies (Ephemeroptera) of the far western United States. Part 3: California. Transactions of the American Entomological Society 134(3+4): 337-430.

McDunnough, J. 1931. The eastern North American species of the genus Ephemerella and their nymphs (Ephemeroptera). Canadian Entomologist 63: 187-197, 201-216.

Needham, J.G. 1927. The Rocky Mountain species of the mayfly genus Ephemerella. Annals of the Entomological Society of America 20:107117.

Ogden, T.H., J.T. Osborne, L.M. Jacobus and M.F. Whiting, 2009. Combined molecular and morphological phylogeny of Ephemerellinae (Ephemerellidae: Ephemeroptera), with remarks about classification. Zootaxa 1991: 28-42.

Parker, C.R., O.S. Jr. Flint, L.M. Jacobus, B.C. Kondratieff, W.P. McCafferty and J.C. Morse. 2007. Ephemeroptera, Plecoptera, Megaloptera, and Trichoptera of Great Smoky Mountains National Park. Southeastern Naturalist, Special Issue 1: 159-174.

Traver, J.R. 1935. Part II: Systematic. North American mayflies order Ephemeroptera; p. 237-739 In: J.G. Needham, J.R Traver, and Y.C. Hsu (eds.). The biology of mayflies. Ithaca: Comstock.

Randolph, R.P. and W.P. McCafferty. 1998. The diversity and distribution of the mayflies of Illinois, Indiana, Kentucky, Michigan, Ohio, and Wisconsin. Ohio Biological Survey Bulletin, New Series 13: 1-188.

Sarver, R. and B.C. Kondratieff. 1997. Survey of Missouri mayflies with the first description of adults of Stenonema bednariki (Ephemeroptera: Heptageniidae). Journal of the Kansas Entomological Society 70(2): 132-140.

Walley, G.S. 1927. Ephemeroptera; p. 59-61 In Criddle, N. (ed). The entomological record, 1926. Annual Report of the Entomological Society of Ontario 57: 47-62.

RECEIVED: December 2009

REVISED: May 2010

ACCEPTED: May 2010

Published ONLINE: June 2010

EDITORIAL RESPONSIBILITY: André V. L. Freitas 